\title{
Politeness Strategy: A Comparative Study on Balinese and Javanese Varieties
}

\author{
Kadek Heni Oktarina Wisudayanti \\ kadekoktarina09@gmail.com \\ STKIP Agama Hindu Singaraja, 81113, Indonesia
}

\begin{abstract}
As human being, people need a way to deliver message or idea to other people by communication. By using language, people can make a relationship with other people in their life. Indonesia has various tribes with their culture, customs, and especially dialects. Among of the dialects are Balinese and Javanese. The Balinese and Javanese have repertoires. In Balinese called by Sor Singgih and in the Javanese called by Ngoko and Krama. The study is entitled "Politeness Strategy: A Comparative Study on Balinese and Javanese Varieties" is about the comparative politeness of Balinese-Javanese varieties in Buleleng Regency, Bali, especially in the word of repertoires between Balinese and Javanese. This research is intended to identify the application of varieties of Balinese in Buleleng Regency, Bali, to identify the application of varieties of Javanese in Buleleng Regency, Bali and to identify the comparison of the usage of varieties of Balinese and Javanese. This study was limited only on the word in the Balinese and Javanese repertoires. The method applied in this research is descriptive qualitative in nature and the data are from the 20 informants from Bali and Java that originally lived in Buleleng. This study used triangulation method by Miles and Huberman (1994) for analyzing the data. The result showed that, the application are focused in the politeness strategy of Balinese and Javanese on the word of Balinese and Javanese itself. The word that comparison of the usage of varieties between Balinese and Javanese are head, face, eye, nose, mouth, teeth, stomach and hand. The similarities of Balinese and Javanese is same in the politeness. It means that when the people from Bali or Java speak to other people, they must concern who speak that they speak. It is for by older persons towards younger persons, by high class society towards low class society, or by speakers in informal conversation.
\end{abstract}

Published by IJRP.ORG. Selection and/or peer-review under responsibility of International Journal of Research Publications (IJRP.ORG)

Keywords: language; politeness strategy; Balinsese and Javanese repertoires.

\section{Introduction}

The language plays an important role as a means of communication in social life. Bloomfield (1979: 3) asserts that language plays a great part in people life. As social creatures that live together with the others, people need language to make an interaction. Language is very significant in communicating ideas, feelings, experiences, and emotions. Language is one of the important things in communication. People live in a world of language. By using language, people can make a relationship with other people in their life. Language has a function to make a relationship with other people. It is supported by Wardhaugh (1986: 1) as follows "Language is what the member of a particular society speak". The quotation above implies that language has a function to make a relationship with other people. Brown (2000: 5) asserts that language is a system of arbitrary conventionalized vocal, written, or gestural symbols that enable members of a given community to communicate intelligibly with one another. Based on the theory above, language is a system of 
communicating with other people using sounds, symbols and words to express the idea and meaning of the people.

Language is a way to communicate ideas comprehensibly from one person to another in such a way that the other will be able to act exactly accordingly. People transfer such ideas acquired by either verbal expression, signing in alphabet (written word), or even signing with gestures and images. Nasr (1984: 1) asserts that language is a part of culture; it is a part of human behavior, language is an acquired habit of systematic vocal activity representing meanings coming from human experiences. Thus language is considered to be an exclusively human mode of communication and also like a bridge in making relationships. Human being absolutely cannot be separated from language. By using language, people undergo their life colorfully. People have differences in language their use. The differences usually may be thorough country boundaries, population culture, demographics and history. Each country through combinations of blending cultures, environment, and other factors has evolved their own unique style of language.

Indonesia has various tribes with their culture, customs, and especially dialects. Among of the dialects are Balinese and Javanese. The Balinese and Javanese have a lot of differences but they have similarities. The similarities in Balinese and Javanese, to speak to other person they must concern who speak that they speak. It is for by older persons towards younger persons, by high class society towards low class society, or by speakers in informal conversation. It is purpose is to make more polite with they speak to the other people. However, in Balinese and Javanese also have differences, especially in a word of repertoires. Sometimes the word of repertoires can be contradictory. In the Javanese is fine (bahasa halus) but coarse (bahasa kasar) in Balinese. The fine language in Bali, whereas become coarse language in Java.

This articles describes the application of varieties of Balinese in Buleleng Regency, Bali, the application of varieties of Javanese in Buleleng Regency, Bali and the comparison of the usage of varieties of Balinese and Javanese, especially in the word of repertoires between Balinese and Javanese.

\section{Theoritical Framework}

\section{A. Language and Culture}

All people use language to share their ideas, opinions, or even disagreements. The languages they speak are different in some respects. The differences of their languages exist because of divergent cultural backgrounds. In other words, the languages have been influenced by their cultures. Language can not be separated from culture because language is the result of the culture of a complex society and active. Language is the most important aspect in studying the life and culture of the people. Language is part of culture. That is, the positions of the language are in subordinate positions in the culture, but they are related each other. However, the relationship between language and culture is the coordination of relations, equal and equally high position. Therefore, it is necessary to learn the language if the people want to explore a culture through its language. The language is a product of culture and at the same time conveys container from the language of the culture in question.

Hence, people have their own varieties to speak to others based on the region, gender, age, social status, and profession. In relation to language and culture, Nasr asserts that language is a part of culture; it is a part of human behavior (1984: 1). That is why language is considered as an exclusively human mode of communication.

On the whole, language and culture are related to each other. Language as a means of communication makes it possible for people to share their culture directly. Culture can not exist without language and vice versa. Therefore, both language and culture seem to be the essential factors in language and society. 


\section{B. Language and Society}

Languages in society eventually become habits that are passed from generation to generation, until the language of the society into a culture that became a hallmark of the community. Language determines not only the culture but also the mindset of people in a region. To understand the culture of a particular area then the first thing that is needed is to understand the language of the community. Language is a tool for people to interact with others. Thus every member of society must have and use the tools of social communication. There is no language without society and no society without language anyway.

There are many definitions about language. It depends on each people in defining the language itself. According to Wardhaugh (2006: 1) "Language is what the members of a particular society speak". It means that language is the part of society itself. Language has never got out of society, language includes in it as reference to society. The definition of language and society are closely related. A considerable variety of ways in which language and society are related there are variety of possible relations between language and society stated by Wardhaugh (2006: 10);

1. One is that social structure may either influence or determine linguistic structure and/ or behavior.

2. A second possible relationship is directly opposed to the first: linguistic structure and/ or behavior may either influence or determine social structure.

3. A third possible relationship is that the influence is bi-directional: language and society may influence each other.

4. A fourth possibility is to assume that there is no relationship at all between linguistic structure and social structure and that each is independent of the other.

Language is used by society to interact and communicate each other. Coulmas (1997: 2) asserts that sociolinguistics is concerned with describing language use as a social phenomenon and, where possible, it attempts to establish causal links between language and society. Society as language users consisting of various members who have different backgrounds such as age, sex, education, and employment. Every member of society is of course a variety of activities as well. Or simply to say every people have their own business. The diversity of backgrounds and people activities as a member of society ultimately impact the diversity of languages that people use as a communication tool.

\section{B. Sociolinguistics}

Humans are social creatures. Humans interact, collaborate, and establish contacts within the community. In doing so, people need a means of communication in the form of language. For this purpose, humans use language as a means of communication as well as group identity. When people communicate, there will be language involved. The role of language in human life is very crucial, since the language is the main tool in communication among society. All the human activities will not occur without the existence of the language. There will be no people or society without language. This can be evidenced by the formation of the various languages of the world have unique characteristics that cause different from other languages. One of branches that studies about society and language is sociolinguistics. According to Yule, (1996: 239) sociolinguistics deals with the inter relationship between language and society. Those definitions show an idea that sociolinguistics is concerns in investigating the relationship between language and society. Sociolinguistics is the study concern about language and society. Holmes (2001: 1) states that sociolinguistics is concerned with the relationship between language and the context in which it is used. Sociolinguistics actually does not discuss a structure of language, but it focuses on how a language is used by the community. Examining the way people use language in different social context provides the information about the way how the language works, especially about the social relationship in a community, and the way people affects the society through the language. It is supported by Fishman (in Chaer and Agustina, 2010:4) as follows “... study of who speak 
what language to whom and when". Sociolinguistics actually does not discuss a structure of language, but it focuses on how a language is used by the community. Fishman (in Chaer and Agustina, 2010: 3) also asserts that sociolinguistics is the study of the characteristics of language of language varieties, the characteristics of their functions, and the characteristics of their speakers as these three constantly interact, change and change one another within speech community.

\section{Language Choice}

Language is a communication tool used by humans to interact with each other. By mastering the language that humans can know the content of the world through science and knowledges of new and has never been seen before. In the current era of globalization, when the relationship and interaction between ethnic groups increasingly wide open, it is very difficult to find groups in which people have only one language or life. Interactions that occur between individuals within the group or other groups led to the development of language live in a society.

The paradigm of language choice in sociolinguistics is not only by linguistics problems alone, but also with the social, cultural, psychological, and situational. In the context of the linguistic situation is a variety of language or variety of language used in social interaction, in-depth study of this important phenomenon. It is such a study of meaningful unit both theoretically and practically. This study is theoretically beneficial to the development of sociolinguistics in general and particular sociolinguistics. It is recognized that the findings of the sociolinguistics and linguistics background of culture and society situation is expected to be a valuable contribution to the discipline of sociolinguistics in general.

In practical terms it means for the study of communication events. The language choice gives insight into the communication events in multilingual communities. In the event the imperative to language choice that matches the communication situations cannot be avoided. Because the mistake of choosing a language can result in losses for the communication of participants. In a multilingual society is a variety of code, either in the form of language, dialect, variety, and style for use in social interaction. With the availability of the codes, the people will choose the code provided in accordance with the factors that influence it. In daily interactions, members of the community are constantly changing variations in usage of the language.

The language choice is used by people in community who speak more than two languages. According to Fasold (1984: 180) the selection of languages is not as simple as people imagine, choosing a language as a whole (whole language) in a communication event. The people imagine a person who controls two or more languages to choose which language they use. It means that people in the community who speak the two languages or more have to choose which one should be used. For example, someone who can speak Javanese and Indonesian languages have to choose one of the two languages when speaking to others in the event of communication.

\section{Language Varieties}

Language is the key essential to human life on earth, because of the language people can interact with each other and language is a resource for life. The language can be used when the people in mutual understanding closely related to the use of language resources that they have. They can understand the intent and purposes of others speak if they listen well to what they said. For that uniformity the language is very important, so communication goes smoothly. Language variation caused by social interaction activities undertaken by the community or a group of highly diverse and due by speakers are not homogeneous. In terms of language variation, there are two views. First, the variation was seen as a result of social diversity and the diversity of speakers of the language that language functions. So, the language variations that occur as a result of social diversity and the diversity of language function. Second, variations of the language already exist to fulfill its function as a means of interaction in a wide range of community activities. Both views can be accepted or 
rejected. Clearly, the variation of the language can be classified based on the presence of social diversity and function of social activities in the community. The variation is based on some factors, such as gender, social class, regional, occupation etc. all of the factors create particular kind of linguistic skill.

\section{E. Dialect}

Humans are social beings who can not live alone but must necessarily always interact with each other. For this purpose, humans use language as a means of communication as well as group identity. This can be evidenced by the formation of distribution language in the world has unique characteristics that cause it different from other languages.

Dialect is the language diversity of the group of speakers, the relative amounts, one region, place, or a particular area. So that could be referred to as a dialect area, regional dialects, and dialect geography. Although each speaker of these dialects has idiolects, but there are features of the language suggests that they use one dialect. And when it interacts with other dialect speakers who also have characteristics he can still be identified from where her family originated.

Dialect is variation of language. The term dialect is sometimes used only if there is a strong tradition of writing in the local variety, (Wardhaugh, 1986: 41). It means that dialect is influenced by tradition in local variety. The variation of language can be defined by the place of participant do communication.

People are separated from one another by fine language gradations of social class, regional origin, and occupation; by factors such as religion, gender, nationality, and ethnicity; by psychological differences such as particular kinds of linguistics skills, e.g., verbality Speech Community or literacy; and by personality characteristics. These are but some of the more obvious differences that affect individual variation in speech, (Wadhaugh, 2006: 130-131). It means that variation of speech is caused by some factors, such as gender, social class, regional, occupation etc. all of the factors create particular kind of linguistic skill.

There are two kinds of dialect variety, they are regional dialect and social dialect:

a. Regional Dialect

Regional Dialect is the kind of dialect which is related with geographical. Regional dialect marks off the resident of one region from those of other regions (Wardhaugh, 2006: 135). It means that resident can be known its region based on its regional dialect. Wardhaugh (2006: 139), “.... People from various locations throughout a wide geographical area will allow the dialect geographer to show where particular sounds, forms, and expressions are used, and where boundaries can be drawn around these so that area A may be described as an area in which linguistic feature X occurs (or is used) whereas area B has no instances of that feature. It means that each area and participants have different linguistic features such as sound, form, and expression is used. Regional dialects also about the pronunciation, vocabulary, and grammar. Holmes (2001: 142) states, "Regional dialects involve features of pronunciation, vocabulary, and grammar which differ according to the geographical area the speakers come from". It means that regional dialect has different pronunciation, vocabulary, and grammar according to geographic area.

b. Social Dialects

Social dialects would be variety associated with a specific social class or group, marking that class or group off from other classes or group (Wadhaugh, 2006: 135). It means that social dialects come from particularly social class or group. Whereas regional dialects are geographical based, social dialects originate among social groups and are related to a variety of factors, the principal ones apparently being social class, religion and ethnicity (Wardhaugh, 2006: 49). It means that social dialects does not based on geographical but it can arise from region, social class or ethnicity. Based on those definitions, social dialects is language variety can arise from social class, religion and 
ethnicity. Geographical does not influence the language variety. It means that participants can come from any region but the participant does activities in certain social class, so it creates social dialects.

\section{F. Balinese and Javanese Repertoires}

Language is a tool of communication in everyday life. When someone speaks, besides pay attention to the rules of grammar, it is also still have to pay attention to who the person they are talking to. Talk to the parents is differently by talking to the person in the same age. Javanese and Balinese have repertoires. It means that to speak to an older person they must concern who speak that they speak. It is for by older persons towards younger persons, by high class society towards low class society, or by speakers in informal conversation. Repertoire is the range or number of skills, aptitudes, or special accomplishments of a particular person or group. (http://www.thefreedictionary.com/repertoire). Repertoire is a range of varieties from which people select according to the context in which they are communicating. (Holmes, 2001: 7).

In the Balinese, there are repertoires to speak with other people. According to Kamus Bali-Indonesia by Dinas Pendidikan Dasar Provinsi Bali (in Nyoman Putra, 2008: 69), "Kata Sor berarti bawah, Singgih berarti halus atau hormat. Sor Singgih Basa Bali berarti aturan tentang tingkatan-tingkatan atau tinggi rendahnya rasa dalam berbahasa Bali". Sor Singgih is very important for the Bali's people when they are speaking with other people. Nyoman Putra (2008: 71) asserts that "Penggunaan Sor-Singgih Bahasa Bali ini akan sekaligus mencerminkan identitas dan status sosial diantara mereka sebagai pembicara dan lawan bicara".Then, Nyoman Putra (2008: 72) asserts that "Tingkatan-tingkatan Bahasa Bali ini juga dipakai untuk membawakan arti-arti kesopansantunan yang berjenjang atau bertingkat-tingkat". It can concluded that when the Bali's people use the Sor Singgih in their conversation it can be show their identity and social status. Sor Singgih also can be show the level of politeness.

Koentjono (in Nyoman Putra, 2008: 73) states that "Penggunaan tutur dapat berfungsi sebagai sarana edukasi dalam melatih manusia khususnya kaum muda, memperhatikan situasi social, dan menghormati manusia lain, serta memupuk kerendahan hati yakni kejujuran terhadap adanya perbedaan social antar manusia (bukan feodalis)". It means that the purpose of use repertoires in the conversation is for education, more respect with other people, social situation, and low profile. This purpose especially for young generation.

In the Javanese, also there are repertoires to speak with other people. Wedhawati et all (2006: 10-11) state that, "Berdasarkan tingkat tuturnya bahasa Jawa dapat dibagi menjadi tiga, yaitu bahasa Jawa ngoko ( $\mathrm{Ng}$ ), bahasa Jawa madya (Md), dan bahasa Jawa krama (Kr)". They also state that, "Tindak tutur Ngoko digunakan untuk komunikasi dengan orang yang sudah akrab atau status sosialnya sederajat. Tingkat tutur Krama digunakan untuk berkomunikasi dengan orang yang belum akrab benar dan status sosialnya lebih tinggi. Tingkat tutur Madya digunakan untuk komunikasi dengan mitra bicara yang status sosialnya lebih rendah dari pembicara". It can conclude that in Javanese there are three speech levels ngoko, madyo and krama. Ngoko has the function to make the conversation more intimate or no distance status including age, krama has a function to respect the other person when the conversation is held and madya is commixture of krama and ngoko.

\section{G. Multilingualism}

A person of different languages or multilingual society is a society that has several languages. Multilingualism is the act of using, or promoting the use of, multiple languages, either by an individual speaker or by a community of speakers. Multilingualism is becoming a social phenomenon governed by the needs of globalization and cultural openness. Sumarsono (2010: 76) asserts that multilingual is a society that has several languages. Such communities occur because some ethnic helped shape the society in terms of ethnicity that can be regarded as a plural society (plural society). 
Multilingualism is a one of the social situation in the sociolinguistics. According to Trudgill, Multilingualism is a sociolinguistic situation in which more than one language is involved (2003: 90). Besides, Francis (1958: 39) also asserts that Multilingualism is parts of the world where people habitually speak more than one language. From those quotations above it can concluded that in the society, if there are people in each communities use more than one language, it is called by Multilingualism

The development of monolingual language became bilingual and multilingual eventually be caused by many factors. The development of communication technology, globalization, and rapid education needs of the community led to a shift of the language as well as the progress of time indirectly confound between languages. The understanding of multilingualism is evolving from a strict sense to the notion that loose.

Multilingualism is as symptoms such as language acquisition identity of speakers (native speakers). This constraint implies the understanding that a bilingual is a person who mastered two languages equally well. Multilingualism is not a symptom of language as a system of narrative but as a symptom, not the code but a characteristic feature of the disclosure; not the individual but a social nature, and also the characteristics of language use. Multilingualism is defined as the practice of using two or more languages in turn by a speaker. Conditions and situations faced by bilingual there are helped determine the turn of the languages used.

\section{Methods}

Research is very general term for an activity that involves finding out, in a more less systematic way, things do not know. "Research is a systematic process of inquiry consisting of three elements or components: (1) a question, problem, or hypothesis, (2) data, (3) analysis and interpretation of data" (Nunan, 1992: 3). In this research, the researcher uses qualitative approach. According to Moleong, (2010: 6):

"Penelitian kualitatif adalah penelitian yang bermaksud untuk memahami fenomena tentang apa yang

dialami oleh subjek penelitian, misalnya perilaku persepsi, motivasi tindakan dan lain-lain, secara holistic dan dengan cara deskripsi dalam bentuk kata-kata, bahasa pada suatu konteks khusus yang alamiah dan dengan memanfaatkan berbagai metode ilmiah".

Then, Nunan (1992: 3) states that qualitative research on other hand, assumes that all knowledge and research is relative, that there is a subjective element to all knowledge and research, and that holistic, ungeneralisable studies are justifiable. Bogdan and Biklen (2007: 5) state that qualitative research is descriptive. The data collected take the form of words or pictures rather than numbers. The written results of the research contain quotations from the data to illustrate and substantiate the presentation. The data includes interview transcripts, field notes, photograph, videotapes, personal documents, memos, and other official records.

The research is descriptive qualitative. Qualitative research of this study is to describe the politeness strategy: a comparative study on Balinese and Javanese varieties in Buleleng Regency, especially in a word of Balinese and Javanese repertoires. The observation is taken from social situation. The interview is taken from the informant. There were 10 informants from Bali and 10 informants from Java lived in Buleleng Regency. Marshall and Rossman (2006: 97) state that qualitative research typically rely on four methods for gathering information: (a) participating in the setting, (b) observing directly, (c) interviewing in depth, and (d) analyzing documents and material culture. Generally, the variations of collecting data consist of observation, interview, and documentation. In this research, the researcher uses observation, interview, and documentation to find the data. Interview is the important thing in this research. According to Esterberg in Sugiyono (2012: 231) interview is a meeting of two persons to exchange information and idea through question and responses, resulting in communication and joint construction of meaning about a particular topic. It means that is an exchange of information about a topic and this information is the data for the researcher. Stainback in Sugiyono (2012: 232) suggests, "Interviewing provide the researcher a means to gain a deeper understanding 
of how the participant interpret a situation or phenomenon than can be gained through observation". According to Suharsimi Arikunto (2002: 132), "Wawancara adalah sebuah dialog yang dilakukan oleh pewawancara (interviewer) untuk memperoleh informasi dari terwawancara "(interviewer)". Interviewing depends on self report. It is clear that interviewing technique is one of data collection techniques that happen between the respondent and correspondents to get information about a topic and that information is the data. The research used the semi structured interview. According to Sugiyono (2012: 233):

"Wawancara semi terstruktur sudah termasuk dalam kategori in-depth interview, dimana dalam pelaksanaannya lebih bebas bila dibandingkan dengan wawancara terstruktur. Tujuan dari wawancara jebis ini adalah untuk menemukan permasalahan secara lebih terbuka, dimana pihak yang diajak wawancara diminta pendapat, dan ide-idenya. Dalam melakukan wawancara peneliti perlu mendengarkan secara teliti dan mencatat apa yang dikemukakan oleh informan".

It means that semi structure interview can be in depth interview and the planning is free in order to the researcher can find the problems more free. The triangulation method used to get the data. According to Miles and Huberman (1994: 10-12), there are three elements which are considered as follows:

1. Data Reduction

Data Reduction is first process of data analysis. It refers to process of selecting, focusing simplifying, abstracting, and transforming the data. In this research, the data is the differential meaning of repertoires in the Javanese and Balinese. First of all, the researcher studies about all of data which have been collected. Then, researcher reduces and chooses the politeness strategy of repertoires in the Balinese and Javanese. And it focused on the word of repertoires in the Balinese and Javanese.

2.Data Displays

Data display is second process of data analysis. Displays help researcher to present the data especially in analyzing words of repertoires in the Balinese and Javanese. In this process, the data are displayed by using table. It has function to make easier to researcher when process the data and make conclusion of the politeness strategy of repertoires in the Balinese and Javanese, especially in word of repertoires which is found previously.

3.Conclusion Drawing/Verification

Conclusion drawing is the last process of data analysis. In this step, the researcher concludes the data, it relates to research problem. Then, making a conclusion which is appropriate. In this process researcher concludes all of the politeness strategy of repertoires in the Balinese and Javanese, especially in word of repertoires.

\section{Results and Discussions}

\section{A. The Applications of Varieties of Balinese}

The applications of varieties of Balinese are especially in word of repertoires. The word of repertoire in Balinese, it's called by Sor Singgih. The application of varieties of Balinese, it can be show in this sentences as follows:

a. Sleep

The English sentences:

- My father sleeps on the bed.

- My brother/sister sleeps at a half past four.

In Balinese, the Singgih of sleep is sirep and the Sor is pules. The use of Balinese repertoires can show in the sentences:

- I Bapa sirep di baleen 
- Ayah tidur di tempat tidur

From the sentence above, it is clear that the word "sirep" is the use of Balinese repertoires. It is Singgih and aimed to an older person. The older person mentioned in the sentence is the father.

- Adine pules jam setengah lime

- Adik tidur jam setengah lima

From the sentence above, it is clear that the word "pules" is the use of Balinese repertoires. It is Sor and aimed to younger person. The younger person mentioned in the sentence is the brother or sister.

b. Eat

In English sentences:

- "Mom, please enjoy it".

- "I had finished eating dinner.

In Balinese, the Singgih of eat is ngajeng and the Sor is medaar. The use of Balinese repertoires can show in the sentences:

- "Meme, durusang mangkin ngajeng".

- "Ibu, silahkan makan sekarang”.

From the sentence above, it is clear that the word "ngajeng" is the use of Balinese repertoires. It is Singgih and aimed to an older person. The older person mentioned in the sentence is the mother.

- Icang pun suud medaar peteng

- Saya sudah selesei makan malam

From the sentence above, it is clear that the word "medaar" is the use of Balinese repertoires. It is Sor and aimed to ourself.

c. Bring

In English sentences:

- He brings one, She brings two

- My friend bring $3 \mathrm{~kg}$ of oranges

In Balinese, the Singgih of bring is makta and the Sor is ngabe. The use of Balinese repertoires can show in the sentences:

- Ipun makta asiki, Ida makta kakalih

- Ia membawa satu, Beliau membawa dua

From the sentence above, it is clear that the word "makta" is the use of Balinese repertoires. It is Singgih and aimed to high class society. The high class society mentioned in the sentence is Ida. Ida in Bali is the high class society.

- Timpal icange ngabe juuk telung kilo

- Teman saya membawa jeruk tiga kilogram

From the sentence above, it is clear that the word "ngabe" is the use of Balinese repertoires. It is Sor and aimed to the person that same age. The person that same age mentioned in the sentence is friend.

\section{B. The Applications of Varieties of Javanese}

The application of varieties of Javanese it can be show in this sentences as follows:

a.Take a Bath

In English sentences:

- “Grandmother, have you taken a bath? 
- I take a bath at four o'clock.

In Javanese, the Krama of take a bath is siram and the Ngoko is adus. The use of Javanese repertoires can show in the sentences:

- "Menapa eyang sampun siram?"

- "Apakah nenek sudah mandi?"

From the sentence above, it is clear that the word "siram" is the use of Javanese repertoires. It is Krama and aimed to an older person. The older person mentioned in the sentence is grandmother.

- Aku adus jam papat

- Saya mandi jam empat

From the sentence above, it is clear that the word "adus" is the use of Javanese repertoires. It is Ngoko and aimed to our self.

b. Come

In English sentences:

- The Head of Village has come from the office

- My friend just came from Surabaya

In Javanese, the Krama of come is rawuh and the Ngoko is teka. The use of Javanese repertoires can show in the sentences:

- Pak Kades sampun rawuh dhateng Kantor Desa

- Pak Kades sudah datang dari Kantor Desa

From the sentence above, it is clear that the word "rawuh" is the use of Javanese repertoires. It is Krama and aimed to an older person or high class society. The older person or high society mentioned in the sentence is the head of the village.

- Kancaku lagek teka saka Surabaya

- Temanku baru datang dari Surabaya

From the sentence above, it is clear that the word "teka" is the use of Javanese repertoires. It is Ngoko and aimed to the person that same age. The person that same age mentioned in the sentence is friend.

c. Out

In English sentences:

- Mr. Aditya is going out of here for few minutes

- I leave out from school at a half past twelve

In Javanese, the Krama of out is miyos and the Ngoko is metu. The use of Javanese repertoires can show in the sentences:

- Pak Aditya kala wau taksih miyos sekedap

- Pak Aditya tadi masih keluar sebentar

The sentence above, it is clear that the word "miyos" is the use of Javanese repertoires. It is Krama and aimed to an older person. The older mentioned in the sentence is Mr. Aditya.

- Aku metu saka sekolah setengah siji

- Saya keluar dari sekolah jam setengah satu

From the sentence above, it is clear that the word "metu" is the use of Javanese repertoires. It is Ngoko and aimed to our self.

\section{B. The Comparison of The Usage of Varieties of Balinese and Javanese}

The comparison of the differences is in the word of repertoires. The comparison usage of varieties of Javanese and Balinese is explained as follows:
a. Head 
Based on the An English - Indonesian Dictionary, head in Indonesian means kepala. In the Kamus Bahasa Indonesia- Bali, kepala means sirah and in the Pepak Basa Jawa means sirah. Sirah in Balinese is the Singgih, the word that fine but in Javanese sirah is the Ngoko, the word that coarse. So, sirah is the comparison of the usage of varieties between Balinese and Javanese

b. Face

Based on the An English - Indonesian Dictionary, face in Indonesian means wajah. In the Kamus Bahasa Indonesia- Bali, wajah means rai. In the Pepak Basa Jawa wajah means rai. Rai in Balinese is the Singgih, the word that fine but in Javanese rai is the Ngoko, the word that coarse. So, rai is the comparison of the usage of varieties between Balinese and Javanese

c. Eye

Based on the An English - Indonesian Dictionary, eye in Indonesian means mata. In the Kamus Bahasa Indonesia- Bali, mata means paningalan. In the Pepak Basa Jawa mata means paningal. Paningalan in Balinese is the Sor, the word that coarse but in Javanese paningal is the Krama, the word that fine. So, paningal is the comparison of the usage of varieties between Balinese and Javanese.

d. Nose

Based on the An English - Indonesian Dictionary, nose in Indonesian means hidung. In the Kamus Bahasa Indonesia- Bali, hidung means irung. In the Pepak Basa Jawa hidung means irung. Irung in Balinese is the Singgih, the word that fine but in Javanese irung is the Ngoko, the word that coarse. So, irung is the comparison of the usage of varieties between Balinese and Javanese.

e. Mouth

Based on the An English - Indonesian Dictionary, mouth in Indonesian means mulut. In the Kamus Bahasa Indonesia- Bali, mulut means cangkem. In the Pepak Basa Jawa mulut means cangkem. Cangkem in Balinese is the Singgih, the word that fine but in Javanese cangkem is the Ngoko, the word that coarse. So, cangkem is the comparison of the usage of varieties between Balinese and Javanese.

f. Teeth

Based on the An English - Indonesian Dictionary, teeth in Indonesian means gigi. In the Kamus Bahasa Indonesia- Bali, gigi means untu. In the Pepak Basa Jawa gigi means untu. Untu in Balinese is the Singgih, the word that fine but in Javanese untu is the Ngoko, the word that coarse. So, untu is the comparison of the usage of varieties between Balinese and Javanese.

g. Stomach

Based on the An English - Indonesian Dictionary, stomach in Indonesian means perut. In the Kamus Bahasa Indonesia- Bali, perut means weteng. In the Pepak Basa Jawa perut means weteng. Weteng in Balinese is the Singgih, the word that fine but in Javanese weteng is the Ngoko, the word that coarse. So, weteng is the comparison of the usage of varieties between Balinese and Javanese.

h. Hand

Based on the An English - Indonesian Dictionary, hand in Indonesian means tangan. In the Kamus Bahasa Indonesia- Bali, tangan means tangan. In the Pepak Basa Jawa tangan means tangan. Tangan in Balinese is the Singgih, the word that fine but in Javanese tangan is the Ngoko, the word that coarse. So, tangan is the comparison of the usage of varieties between Balinese and Javanese.

\section{Conclusion}

The Balinese and Javanese is a part of the culture of Bali and Java. The Balinese and Javanese as a cultural index of Bali and Java, also as a cultural symbol of Indonesia. The comparison of the similarities in the Javanese and Balinese is same in the politeness. It means that when the people from Java and Bali speak to other people, they must concern who speak that they speak. It is for by older persons towards younger 
persons, by high class society towards low class society, or by speakers in informal conversation. The application is focused in the politeness strategy of Javanese on the word of Javanese. The fine language is Krama and the coarse language is Ngoko. The application is focused in the politeness strategy of Balinese on the word of Balinese. The fine language is Singgih and the coarse language is Sor. The comparison of the usage of varieties of Javanese and Balinese is focused in the politeness strategy of Javanese and Balinese on the word. The word that comparison of the usage of varieties between Balinese and Javanese are head, face, eye, nose, mouth, teeth, stomach and hand. Then, the comparison of the similarities in the Javanese and Balinese is same in the politeness. It means that when the people from Java and Bali speak to other people, they must concern who speak that they speak. It is for by older persons towards younger persons, by high class society towards low class society, or by speakers in informal conversation.

\section{References}

Abdul, Chaer and Leonie, Agustina. 2010. Sosiolinguistik: Perkenalan Awal. Jakarta: Rineka Cipta.

Bloomfield, Leonard. 1933. Language. London: George Allen and Unwin Ltd.

Bogdan, Robert \& Biklen. 2007. Qualitative Research for Education An Introduction to Theory and Methods. London: Allyn and Bacon.

Brown. H. Douglas, 2000. Principles of Language Learning and Teaching Fourth Edition. New York: Longman

Coulmas, Florian. 1997. The The Handbook of Sociolinguistics. Oxford: Blackwell Publishing Ltd

Echols, John M. and Hassan Shadily. 1992. Kamus Indonesia-Inggris. Jakarta: PT. Gramedia.

Echols, John M. and Hassan Shadily. 1992. Kamus Inggris-Indonesia. Jakarta: PT. Gramedia.

Fasold, Ralph. 1989. The Sociolinguistics of Society. New York: Basil Blackwell.

Francis, Nelson. 1958. The Structure of American English. New York: The Ronald Press Company

Holmes, Janet. 2001. An Introduction to Sociolinguistics, Second Edition. London: Longman

I Nyoman Putra Suarjana,. 2008. Sor Singgih Basa Bali, Ke-bali-an Manusia Bali Dalam Dharma Papadikan, Pidarta, Sambrama Wacana dan Dharma Wacana. Denpasar: Tohpati Grafika Utama

Marshall \& Rossman. 2006. Designing Qualitative Research. California: Sage Publications, Inc.

Miles, B. Mathew and Huberman, Micael. A. 1994. An Expanded Sourcebook: Qualitative Data Analysis. London: Sage Publications

Moleong. 2010. Metodologi Penelitian Kualitatif. Bandung: Pt. Remaja Rosdakarya Offset.

Nasr. Raja T. 1984. The Essentials of Linguistic Science. London: Longman Group Limited

Nunan, David. 1992. Research Methods in Language Learning. Cambridge: Cambridge University Press.

Suharsimi, Arikunto. 1998. Prosedur Penelitian: Suatu Pendekatan Praktek. Jakarta: PT. Rineka Cipta

Sumarsono,. 2010. Sosiolinguistik. Yogyakarta: Sabda

Wardhaugh. Ronald. 2006. An Introduction to Sociolinguistics. USA: Basil Blackwell Ltd.

Wedhawati et all. 2006. Tata Bahasa Jawa Mutakhir. Yogyakarta: Kanisius

Yule, George. 1996. The Study of Language. Second Edition. Cambridge: Cambridge University Press. 